\title{
Social Analysis of Policy Implementation Regional Head Election Voter Registration in North Sulawesi Province
}

\author{
Zulkifli Golonggom ${ }^{\mathbf{1}}$, Heru Nurasa ${ }^{\mathbf{2}}$, Entang Adhy Muhtar ${ }^{\mathbf{3}}$, Caroline Paskarina ${ }^{\mathbf{4}}$ \\ Universitas Padjadjaran, Bandung, Indonesia \\ zgolonggom@gmail.com
}

\begin{abstract}
This study analyzes the social implementation of voter registration policy in the regional head elections in North Sulawesi Province in 2017. According to the eligible residents in the constituency, the process of voter registration through voter list update to produce a voter list is completely fulfilled voting rights. Thus, during the vote, those who have the right to vote can exercise their voting rights. But in the course of the trip, the administrative activities of the preparation of voter lists by the Voter Data Update Officer (PPDP) conducted Matching, and Research (Coklit) encountered obstacles, voter data collection in each village clashed with the constraints of population indifference to be registered as voters and the obligation of recording electronic ID cards, the socioeconomic condition of the community that the majority as farmers prioritize their time and needs with agricultural activities and on the other hand the migration of population because of duties and jobs and work and education outside the electoral district.
\end{abstract}

\author{
Keywords \\ social analysis, policy \\ implementation; public \\ administration; voter list \\ preparation, regional head \\ election
}

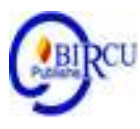

\section{Introduction}

The holding of direct elections in Indonesia is the most complicated and costly general election organization. For example, in organizing the 2014 general election, the costs incurred reached 24 trillion rupiahs, and there were more than 190 million voters spread across Indonesia. This situation is also complicated by the social characteristics and geographic areas of the electoral regions, varying from accessible (urban) to challenging areas, such as residential areas in the mountainous regions inland, islands, and borders (Andrews, 2001).

This situation also applies during the National Staged Regional Head Election's $2015,2017,2018$, and 2020. There are many stages of holding regional head elections that the General Election Commission must prepare from central to regional, one of which is the fulfillment of citizens' voting rights by providing a comprehensive, accurate, and up-todate voter list (Malik, Supriyono \& Mindarti, 2020).

To regulate voter registration, the government has issued various policies to hold voter registration in the implementation of Pilkada, including through Law (UU) Number 10/2016. This Policy has handled the Voter Registration process correctly and adequately so that it is expected to produce a Permanent Voter List (DPT) that accommodates the voting rights of all citizens (Golonggom, Nurasa, Muhtar \& Paskarina, 2020).

However, the implementation of this Policy creates new problems in the simultaneous regional elections in 2017. Regional KPU as the organizer of the Pilkada in 7 (seven) provinces and 76 regencies/cities, has established the DPT for the 2017 Pilkada since the previous year, namely on 6 December 2016. The DPT determined 41,205,115 voters, which were divided into 20,699,261 men and 20,505,854 women. All voters are spread across 98,259 Polling Stations (TPS) (KPU-RI, 2017). 
In its development then at the end of 2016, the General Election Supervisory Agency (Bawaslu) found that there were more than one million people who already had voting rights but had not finished recording their e-KTP, which was used as a condition for being able to exercise their voting rights, and threatened to lose their voting rights (Karsa, 2018).

This problem arises because based on the Data on Potential Election Voters Population (DP4) issued by the Ministry of Home Affairs (Kemendagri) and used by the KPU in compiling the DPT in the 2017 Pilkada, it is inaccurate and not well updated. The weakness of the DP4 preparation is a side effect of the miss of the e-KTP national program, which should have been completed by the end of 2013. In the end, the Ministry of Home Affairs could not fulfill the e-KTP requirement as a voting requirement because the e-KTP recording process was not complete until the end of 2016. Sandi et al (2020) stated that Regional election becomes a holder to put legitimacy in particular region and part of another general election.

In the Simultaneous Pilkada in North Sulawesi Province, although in turn, the pilkada could be held on the Voting Date, 15 February 2017, there was a problem at the Voter Registration stage. This Policy requires that the public must first be registered in the voter list, while to make registered citizens requires population data prepared by the Ministry of Home Affairs through the E-KTP program. Through the Director-General of Population Administration, the fact shows that the Ministry of Home Affairs has not completed the e-KTP recording program (Nadya, 2017). This is because the e-KTP recording program has not been implemented evenly in all corners of the Indonesian country. This situation is, of course, related to the social conditions that occur in the formulation of policies for the implementation of regional head elections, such as social problems surrounding community participation in voter registration; prospective voters have the view that they do not have time to register themselves as voters and take care of recording electronic ID cards because they incur costs compared with the use of time to work that can generate money from agriculture and work. Syofian et al (2020) stated that Indonesia, post-reform elections as a practice of Indonesian and regional political reality and direct regional head elections as part of the embodiment of regional autonomy policies.

Due to the impact of this social problem, the implementation of this voter registration policy is not following the expected output to produce a comprehensive, accurate, and upto-date voter list because there are still voters who should qualify as voters but have not yet entered the voter list due to the absence of possession of an electronic KTP during data collection (matching and checking) of voters by the officer updating the voter list.

\section{Research Methods}

The method used in this research is the descriptive method with the type of case study. Nazir $(1999 ; 22)$. The approach used in this research is a qualitative approach that focuses on facts and uses comparative analysis to make empirical generalizations on social phenomena. Using a qualitative approach, it is hoped that a fundamental understanding (verstehen) of social problems can be obtained holistically and impressively by combining analysis and interpretation of the data presented in a narrative.

Bogdan and Biklen $(1992 ; 29)$ state that a qualitative approach produces descriptive data in the form of written or spoken words from people and observable behavior to understand and explain the occurrence of a process. Qualitative methods are used because this research prioritizes the quality of analysis and not statistical data. Therefore, the answer is not in the form of numbers but words and documentation. Qualitative research is carried out to find a comprehensive and in-depth picture of the object under study; by 
departing from an existing phenomenon, this research also does not leave from a theory to be tested for truth.

This research was conducted at locations in North Sulawesi Province at the General Election Commission of Bolaang Mongondow Regency and Sangihe Islands Regency and which carried out the registration of regional head election voters in 2017 using the Voter Registration Policy instrument, namely KPU Regulation No. 8 of 2016 concerning Data Compilation and Updating of 2017 Regional Head Election Voter List.

\section{Result and Discussion}

\subsection{Implementation of Voter Registration Policy}

Tabel 1. Total Population Age 15 and over

According to Main Work Status and Gender in Bolaang Mongondow Regency in 2017

\begin{tabular}{cccc}
\hline Main Work Status & \multicolumn{2}{c}{ Gender } & \multirow{2}{*}{ Amount } \\
\cline { 2 - 3 }$(\mathbf{1})$ & Male & Female & \\
\hline Freelance & $\mathbf{( 2 )}$ & $\mathbf{( 3 )}$ & $\mathbf{( 4 )}$ \\
\hline Doing business assisted by temporary / unpaid workers & 7,100 & 1,870 & 8,970 \\
\hline $\begin{array}{c}\text { Doing business assisted by permanent workers / paid } \\
\text { laborers }\end{array}$ & 2,511 & 382 & 2,893 \\
\hline Laborer / Employee / Employee & 11,122 & 5,853 & 16,975 \\
\hline Free Agriculture Workers & 17,101 & 4,749 & 21,580 \\
\hline Free Workers outside of Agriculture & 10,307 & 1,139 & 11,446 \\
\hline Unpaid Family Worker & 2,878 & 8,310 & 11,197 \\
\hline Amount & 70,501 & 28,601 & 99,102 \\
\hline
\end{tabular}

Source: BPS Kab, Bolaang Mongondow, 2018

As summarized by the author from the Republic of Indonesia KPU Regulation Number 8 of 2016 concerning Data Compilation and Updating of Regional Head Election Voter List, the implementation of the Voter Registration Policy is carried out through the stages of compiling the voter list as follows:

1. In the process of compiling the Voters List, first the initial data that must be provided by the General Election Commission (KPU) of the Republic of Indonesia is Population Data, namely Potential Population Voters Data (DP4) obtained from the Ministry of Home Affairs, and specifically for the implementation of the Legislative Elections, the President, -The Vice President must be equipped with data on Indonesian citizens residing abroad obtained from the Ministry of Foreign Affairs.

2. Based on DP4 data, the KPU then compiles Voters Data, which is made based on the results of pairing or synchronizing the Final Voters List (DPT) with DP4 to be updated by the Voters List Update Officer (PPDP) conducting Matching and Research (Coklit) to obtain Voter Data Result Update.

3. From the results of the updated voter data, the KPU compiles the Provisional Voters List (DPS), in the future abbreviated as DPS, which the Regency / City KPU carries out with the assistance of the District Election Committee (PPK), the Voting Committee (PPS), and PPDP.

4. The next stage, after compiling the Provisional Voters List, then in the process through several revisions based on input and responses from the community, the District 
Supervisory Committee (Panwascam), and the Campaign Team for Regional Head Candidate Pairs, the KPU compiles the Provisional Voters List for Improvements (DPSHP).

5. The next stage is the preparation of the Final Revised Voters List or Final DPSHP, namely DPSHP, which has been revised based on input and responses from the community, the District Supervisory Committee (Panwascam), and the Campaign Team for the Regional Head Candidate Pair.

6. From the Final DPSHP, a Permanent Voters List (DPT) is compiled, The Final Voters List is the Final DPSHP which has been revised by PPS, recapitulated by PPK, and stipulated by Regency / City KPU / KIP, At this stage, it can be concluded that compiling the Final Voters List is a task that requires a long time and goes through repetitive corrections, This also explains that problems can occur in the field that affects the Final Voters List data's accuracy.

7. The preparation of the Voters List does not stop at the Permanent Voters List; after that stage, the Additional Voters List, abbreviated as DPTb, is still being compiled, namely the List of Voters who have been registered in the DPT at a TPS which due to unavoidable circumstances Voters cannot exercise their right to vote in The polling station in question is written and casts votes at another TPS.

8. After completing the Additional Voters Data, a Special Voters List (DPK) is created, namely a list of voters who have a resident identity but have not registered in the additional DPT and DPT.

The next stage is Updating Voters Data, namely by updating Voter Data based on the last Election / Election DPT, which is updated continuously and juxtaposed with DP4 and checking and researching, This stage is carried out after the Election / Regional Head Election has ended.

Table 2. Total Population by Age and Gender in Sangihe Islands Regency in 2017

\begin{tabular}{cccc}
\hline \multirow{2}{*}{ Age group } & \multicolumn{3}{c}{ Gender } \\
\cline { 2 - 4 } $\mathbf{( 1 )}$ & Male & Female & Amount \\
\hline $0-4$ & 4896 & $\mathbf{( 3 )}$ & $\mathbf{( 4 )}$ \\
\hline $5-9$ & 4898 & 4674 & 9437 \\
\hline $10-14$ & 5529 & 5190 & 10719 \\
\hline $15-19$ & 5773 & 5107 & $\mathbf{1 0 8 8 0}$ \\
\hline $20-24$ & 5199 & 4836 & $\mathbf{1 0 0 3 5}$ \\
\hline $25-29$ & 5145 & 4630 & 9775 \\
\hline $30-34$ & 4677 & 4193 & 8870 \\
\hline $35-39$ & 4419 & 4535 & 8954 \\
\hline $40-44$ & 4978 & 4899 & 9877 \\
\hline $45-49$ & 5242 & 5154 & 10396 \\
\hline 5054 & 4346 & 4212 & 8558 \\
\hline $55-59$ & 3674 & 3704 & 7378 \\
\hline $60-64$ & 2681 & 2882 & 5563 \\
\hline $65+$ & 4225 & 5782 & $\mathbf{1 0 0 1 0}$ \\
\hline Total number & 65682 & 64342 & 130024 \\
\hline
\end{tabular}

Source: Sangihe Islands Regency in Number, 2017 
The nine steps in the Voter Registration process show that everything "boils down" to the determination of the Final Voters List. This process is a very long and complex one, However, it can also be "read" that the voter registration process, which is carried out through updating the voter list, is to produce a Voter List that is entirely accurate or according to the region's population being recorded, So that at the time of voting, all those who have the right to vote can exercise their voting rights and are actual residents of the electoral area (Briwn \& Wedeking, 2006).

\subsection{Match and Research}

Matching and Research activities were carried out starting 8 September 2016. Following their duties, this activity was carried out by the Voters List Updating Officer (PPDP). The implementation period of the Matching and Research activities was 30 days, Voters' data updating officers visit people's homes one by one directly to get factual data. In this Matching and Research activity, PPDP will cross out voters who no longer meet the Model A-KWK Voters List requirements, correct or complete the identity of the Voters in the Model A-KWK Voters List, Not registered in the form on the AA-KWK Model Voters List, submitting a documented Model AA,1-KWK proof, and attaching a Model AA,2KWK registered guarantee sticker on each house that has been checked.

\subsection{Compilation of the Voters List}

The General Election Commission carries out the Administration of Voter List Compilation from 23 to 25 August 2016. The beginning of this activity is downloading the Voters List Results of TPS mapping on the Voter Registration Information System (SIDALIH) portal, After that, the downloaded Voters List was compiled using the Model A-KWK form. The Voters List that has been compiled using form A-KWK is then duplicated according to the number of polling stations and distributed to the Voter Data Update Officer (PPDP) through the District Election Committee. This activity was also directly linked to the Technical Guidance on the Procedure for Updating Voters' Data for Voter Data Updating Officers (PPDP) in each sub-district (Herder \& Krosnick, 20080). This data is administered and recapitulated into the Provisional Voters List, which is then revised by the Voting Committee (PPS) until the final voter's list is established, as described in the previous registration preparation stages.

At the stage of determining the voter list, voters who are registered but do not yet have an electronic KTP are technically entered in the AC, KWK form, as in the Policy set out in KPU Regulation No, 8 of 2016, regarding Voters who do not yet have a KTP to record an electronic KTP and request a certificate from the district/city civil registration service, then if the population and civil registration services do not issue a certificate, it is sent to the RI KPU to be forwarded to The Director-General of Population and Civil Registry of the Ministry of Home Affairs of the Republic of Indonesia to be checked in the population database by category. First, if the voters enter the population database in the electoral area (Bolaang Mongondow district and Sangihe Islands Regency area), they will still be included in the voter list. Second, if it is not in the data population base, before the determination of the final voter list (DPT), it will be crossed out from the Voters List (Article 13A Paragraph 1-3). For this Policy of norms, the number of voters who must be crossed out on the voter list in Bolaang Mongondow Regency is 7,045 voters (Election Report for Bolaang Mongondow Regency) and Sangihe Islands Regency totaling 2,306 voters (Regional Election Report for Kep, Sangihe Regency, 2017), 


\subsection{Social Analysis of Voter Registration Issues}

The number of voters who must be crossed out on the voter list in Bolaang Mongondow Regency is 7,045 voters, and Sangihe Islands Regency is 2,306 voters, meaning that there is a diversity of target groups that are explored through deepening the various difficulties encountered by Voter Data Updating Officers in their efforts to meet Directly with these prospective voters. To obtain varied data, interviews were conducted by taking different locations in these two districts.

The theory used to conduct social analysis is from Mazmanian \& Sabatier regarding the unachieved implementation of policies from the Tractability Aspect of the problem (difficulty level of controlling the pain) related to Target Diversity and Population (1983). The target group is interpreted as prospective voters or community members in Bolaaang Mongondow and Kab in this study, Sangihe Islands

The interviews and field research results show significant differences in characteristics between the target groups of voter candidates in Bolaang Mongondow district and Sangihe Islands. In Bolaang Mongondow district, the social characteristics that stand out the most are the ignorance of the population who, in terms of age, have met the requirements to become voters and the obligation to record an electronic ID card which is eventually crossed out / issued on the voter list. From the results of interviews with informants, it was stated that residents had not prioritized recording at Disdukcapil because for them, what was more critical was working to earn a living for the family. Most people who have this characteristic live in villages with the main livelihood as farmers, smallholders, or garden workers. They are the ones who rely on all the socio-economic needs, both for themselves and their families, from the agricultural sector. So they think that recording is useless, a waste of time and money (Sidiq \& Jalil, 2021),

Meanwhile, the extended distance from the village to the district capital requires many transportation costs and a long time. From West Dumoga sub-district, for example, the distance from this sub-district to the district capital (Lolak sub-district) is $110 \mathrm{~km}$, which must be taken within 1,5 - 2 hours of travel by private transportation. If you use public transport, the travel time will be longer. So recording management requires a maximum time allocation of about 6 hours. For rural residents, they miss the opportunity to work on agricultural land or plantation land one day. In the Bolaang Mongondow district, many gold mining areas are being worked on illegally by the community. They can live for months in this area. They will not leave the mine site until they get a result. Except for buying various necessities while in the mining area, they will "go down" to the city/village. Some residents open new land in the forest because part of the plantation / agricultural land near the town already belongs to other residents. They can also stay for months in the woods and only return to sell their produce or family and village matters or events. For example, if there is a wedding party or other celebration.

The agricultural sector is the second-largest source of livelihood for residents of

Bolaang Mongondow district. Data about this can be seen in the Central Bureau of Statistics of Bolaang Mongondow Regency publication, which is published annually. The 2018 BPS data can be seen in Table 1.

Many agricultural workers in this sector become one of the main obstacles when the KPU of Bolaang Mongondow District, through the Voter Data Update Officer, carries out the voter registration process in the data verification stage; the final step is the determination of the Permanent Voter List. As explained above, agricultural workers are more worried about losing time cultivating land than recording electronic ID cards registered as voters in the Regional Head Election in Bolaang Mongondow Regency in 2017. The problem is that acquiring agricultural land is generally far from residential areas 
in general, so this situation becomes an additional burden for Voters Data Updating Officers, both in terms of time, cost, and energy.

Unlike in Bolaang Mongondow, from the results of field research in the Sangihe archipelago district, from the perspective of the issue of community diversity of prospective voters, the process of implementing voter registration policies in this district is dealing with problems of the migrant population (outside the district) and migration of local people (within the community) to abroad. Districts work as laborers, household assistants, and take education. Migrant residents are residents from outside the area who are then placed in the Sangihe archipelago district because of their duties. They are government agencies, banks, or state-owned enterprises assigned and set in the Sangihe archipelago district. Government agency employees are subject to transfer or rolling employees and then placed or transferred to the Sangihe island district. At this level generally are officials at the level of the Head of Office, or the level of Assistant. They are usually drawn to the provincial level or transferred to other districts on the orders of the provincial-level government or can also represent transfers from the province and/or from other communities in the area of North Sulawesi.

Next are Pertamina employees, who are generally Central employees who are stationed in the regions. Then Bank employees, especially at the level of Branch Heads or Unit Heads and PLN employees, typically experience rolling every two years. They are primarily residents outside the region who have homes and families in the provincial capital, namely in Manado, and some even come from Java. This circulation of their entry/exit then makes it quite tricky for PPDP to accurately record and input voter data in the Regional Head Election in Kab, Sangihe Islands, to be exact.

Another problem is the migration of local people. Part of the population, especially in Tahuna City, especially among the young Civil Servants, have moved a lot from their original place of residence, and then because they are already married or for other reasons, they move to live in new areas such as housing or build new houses on the premises. Another, without reporting to the government (lurah / village head) from the scope of origin. But physically, they are no longer residents or residents in their place of origin. This then makes it difficult for Voter Data Update Officers to carry out their Data Updating duties in compiling and determining the Final Voters List. In their new residence, they are not registered as residents, while they are still administratively registered as residents in the previous area. Prospective voters with this category generally live in residential areas that the developer has just opened. So that in the new residential area, the population has not been recorded. Faced with a situation like this, the Data Updating Officer took the initiative to visit the new residence of the prospective voters.

The results of field research also show that most of the young population (19-25 years) are more outside the region than in the Sangihe Islands. It turns out that this is because most of the young population took their higher education at universities outside the area, especially in the provincial capital, namely in the city of Manado, as well as in Tondano, Kab, Minahasa (Manado State University) and other universities on Java island, especially those taking further studies for Strata 2 and Strata 3. In the Sangihe archipelago district, only one higher education institution is classified as D4, and it focuses more on Vocational Education, skills, and vocational skills, namely the State Polytechnic "Nusa Utara,". In addition, many young people take high school education in Manado and Tomohon. These first-time voters only go home when the semester breaks or year-end holidays. This situation is also quite an obstacle in updating data in the context of updating administration and preparation of voter lists. Data was obtained that many of them had not 
recorded data at the Sangihe Islands Disdukcapil Office. Many of them do not yet have an electronic KTP which is an absolute requirement to be registered as voters.

Based on data from Sangihe District in Figures for 2017, the young population (1519 years) is the largest population group in this district. The second largest group is older adults aged 65 years and over, and the third is the population of young adults, namely from 20-24 years - details in table 2. Of the total population above, the population is young (1524 years). About $80 \%$ of them are implementing education outside the Sangihe archipelago district. There is only 1 (one) higher education level education institution in this regency, namely the Polytechnic of North Nusa Tenggara, only 1 State Senior High School, namely in Tahuna city (the capital of the regency), there are also only 1, Vocational Schools, Age group whose daily activities are primarily outside this district. So that this data can strengthen the various obstacles faced by the Data Updating Officer) in carrying out the Matching and Research stages related to the implementation of the Voter Registration Policy through the preparation of the Voter List.

\section{Conclusion}

The implementation of direct General Elections and Regional Head Elections in Indonesia is the most complicated and expensive general election, one of which is the stage of the voter registration process to produce Voter Data that is completely accurate or following population administration data proven by ownership of an electronic KTP and or a certificate from the Regency / City Population and Civil Registry Office, So that at the time of voting, all those who have the right to vote can exercise their voting rights and are actual residents of the electoral region or region.

The implementation of the voter registration policy began with the provision of population data from the Director-General of Population and Civil Registry of the Ministry of Home Affairs in the Form of Election Voter Potential Population Data (DP4), It is paired/synchronized with voter data held by the KPU in the Form of the Final Election /

Election Voters List (DPT), which is then updated and compiled by the Voters List Registration Officer (PPDP), PPS and PPK until the stipulation of the Permanent Voters List (DPT) for Regional Head Election.

\section{References}

Andrews, K, T, (2001), Social movements and policy implementation: The Mississippi civil rights movement and the war on poverty, 1965 to 1971, American Sociological Review, 71-95.

Asy'ari, H, (2012), Arah Sistem Pendaftaran Pemilih Indonesia: Belajar Dari Pengalaman menuju Perbaikan, Jurnal Pemilu \& Demokrasi, 1-34.

Brown, R, D, \& Wedeking, J, (2006), People Who Have Their Tickets But Do Not Use Them: "Motor Voter," Registration, and Turnout Revisited, American Politics Research, 34(4), 479-504.

Bungin, B, (2009), Penelitian Kualitatif, Jakarta: Kencana Prenada Media Group.

Debroy, B,, \& Desai, K, (2017), Analysis of Simultaneous Elections: The "What," "Why," and "How,"

Golonggom, Z, Nurasa, H,, Muhtar, E, A,, \& Paskarina, C, (2020), Implementation of Voter Registration Policy in Simultaneous Regional Elections in North Sulawesi Province, Talent Development \& Excellence, 12(1). 
Harder, J, \& Krosnick, J, A, (2008), Why do people vote? A psychological analysis of the causes of voter turnout, Journal of Social Issues, 64(3), 525-549.

Karsa, T, I, (2018), The Implementation Of Democracy Principles In The Regional Head Election System In Indonesia, In Proceeding of International Conference: $3 \mathrm{rd}$ SHIELD (pp, 322-331).

Kholid, W, M, (2018), The Implementation of Simultaneous Village Head Election Implementation Policy in Realizing Participatory, Transparent, and Accountable Election Process in Local Government in Indonesia, International Journal of Governmental Studies and Humanities (IJGH), 1(2), 48-58.

KPU regulations, (2016), KPU Regulation Number 8 of 2016 concerning Amendments to General Election Commission Regulation Number 4 of 2015 concerning Updating of Data and Voter List in the Election of Governors and Deputy Governors, Regents and Deputy Regents, and/or Mayors and Deputy Mayors.

Malik, A,, Supriyono, B,, \& Mindarti, L, I, (2020), Direct and Simultaneous Regional Head Election in Indonesia with Government Efforts to Build a Balance of Political and Managerial Approaches, East Asia, 37(3), 261-279.

Mazmanian, D, A,, \& Sabatier, P, A, (1981), Effective Policy Implementation, United States: Lexington Books.

Mirin, J, S, (2011), Implementasi Kebijakan Pemilihan Kepala Daerah dan Wakil Kepala Daerah Kabupaten Yahukimo Provinsi Papua Tahun 2011.

Mustofa, A, (2015), Implementasi Kebijakan Pendaftaran Pemilihan Umum Kepala Daerah Kota Batu Tahun 2012, Jurnal Ilmu Sosial dan Ilmu Politik, 4(2), 313-326.

Nadya, N, K, (2017, November), The influence of inclusive policy by the general election commission to the participation rate of voters with disabilities in the 2017 simultaneous regional head elections in Indonesia, In International Conference on Diversity and Disability Inclusion in Muslim Societies (ICDDIMS 2017), Atlantis Press.

Nagpal, D, (2019, Juli 2), Weighing our options on the 'One Nation, One Election' proposal: An explainer, India.

Nugroho, B, P, (2017), Ini Data 7 Provinsi, 18 Kota, dan 76 Kabupaten di Pilkada 2017.

Report on the Implementation of the Election of the Regent and Deputy Regent of Kab, Bolaang Mongondow 2017.

RI Law, (2016), Law Number 10 of 2016 concerning the Second Amendment to Law Number 1 of 2015 concerning Stipulation of Government Regulations in Lieu of Law Number 1 of 2014 concerning the Election of Governors, Regents, and Mayors Into Law.

Riwanto, A, (2016), An Evaluation of Legal Policy Related to the Implementation of the Simultaneous Local Election (a First Indonesia Period of the Simultaneous Local Election), Yustisia, 5(3), 663-678.

Sandi, J. R. A., et al. (2020). Public Perception of the Implementation of Simultaneous Regional Head Election 2020 during Covid-19 Pandemic in Palangka Raya Regency. Budapest International Research and Critics Institute-Journal (BIRCI-Journal) Vol 3, No. 4, Page: 3333-3340

Suadi, (2019), Indonesia Negara Demokrasi Terbesar Ketiga Dunia.

Sidiq, R. S. S., \& Jalil, A. (2021). Virtual World Solidarity: How Social Solidarity is Built on the Crowdfunding Platform Kitabisa. com. Webology, 18(1).

Syofian, E., et al. (2020). Identity Politics in the 2018 Regional Head Elections for the Governor and Deputy Governor of North Sumatra. Budapest International Research and Critics Institute-Journal (BIRCI-Journal) Vol 3, No. 4, Page: 3675-3685 
Tripathi, M, (2019), OPINION | One Nation, One Election: Is Holding Simultaneous Polls Feasible in India?

Waris, I, (2011), Kinerja Komisi Pemilihan Umum (KPU) Kota Palu Dalam Pemilihan Umum Presiden dan Wakil Presiden RI Tahun 2009 di Kota Palu, Indonesian Journal of Dialectics, 1(3), 223-233. 